\title{
From Independence Day to Land of Plenty: Screening American Patriotism from German Émigré Perspectives before and after $9 / 11$
}

\section{Frank Mehring}

\section{(2) OpenEdition \\ Journals}

Electronic version

URL: https://journals.openedition.org/ejas/8682

DOI: $10.4000 /$ ejas. 8682

ISSN: 1991-9336

Publisher

European Association for American Studies

Electronic reference

Frank Mehring, "From Independence Day to Land of Plenty: Screening American Patriotism from German Émigré Perspectives before and after 9/11", European journal of American studies [Online], 5-4 | 2010, document 3, Online since 15 November 2010, connection on 08 July 2021. URL: http:// journals.openedition.org/ejas/8682 ; DOI: https://doi.org/10.4000/ejas.8682

This text was automatically generated on 8 July 2021.

Creative Commons License 


\title{
From Independence Day to Land of Plenty: Screening American Patriotism from German Émigré Perspectives before and after 9/11
}

\author{
Frank Mehring
}

\section{Introduction}

1 "Independence Day" and "Land of Plenty" are two tropes referring to the basis of American national identity: the Declaration of Independence with its guarantee of equal and inalienable rights and the promise of an inexhaustible abundance of resources. Independence Day (aka ID4) and Land of Plenty are also two American feature films directed by German émigrés. The first was a science fiction blockbuster from 1996 by Roland Emmerich, the second an independent road movie from 2003 by Wim Wenders. Both directors are highly regarded in the United States, Emmerich for delivering big budget special effects films with global market revenues, Wenders for critical art-house films appealing to left-wing intellectuals and students attending university film seminars. ${ }^{1}$ Both films confront the issue of American patriotism albeit from different angles and at different times. Independence Day wholeheartedly embraces the American founding myths and translates them into a science fiction scenario. Wenders manoeuvres into an artistic space producing what I call patriotism of dissent. ${ }^{2}$ Both films engage in a kind of dialectic dialogue on American patriotism.

2 When Wenders reflected in his diary on the images he had just seen on CNN on the $11^{\text {th }}$ of September 2001, he shuddered at the sense of familiarity seeing people run in panic from the site of catastrophe followed by a looming cloud of debris and dust. The lustful celebration of destruction in disaster and science fiction films acquired a transgressive character in light of the television sequences from the real site of destruction in downtown Manhattan. "Die Bilder waren eindeutig zu weit gegangen," Wenders 
explained - the images had clearly gone too far. ${ }^{3}$ Shortly after $9 / 11$, he referenced the work of his fellow German émigré filmmaker Roland Emmerich, declaring that:

People dug Independence Day because it sent a pleasant shiver down their spine and the towers of the World Trade Center had been destroyed already five times in film history. There was not a single time that I have enjoyed this. I have never liked to watch things like that. The attacks will now have consequences for a specific genre and a specific kind of special effects. ${ }^{4}$

3 The visual rhetoric of Independence Day served as a negative foil for Wenders's films after the terror attacks. As a key element of American culture, Wenders recognizes an addiction to ever more radical image productions. With the "American dream" being itself a product of the movie industry, the medium perpetuates a longing for beautiful sights which, according to Wenders, ultimately lead to blindness. The terms "Sehnsucht" and "Seh-Sucht" [yearning for and addiction to sights] describe this nexus perfectly well. With Independence Day, the display of American patriotism reached a new level of what Wenders recognizes as national self-delusion. Interestingly, the image production controlled by the Bush administration for the war on terror borrowed heavily from the patriotic formulas which had been so successfully translated to the movie screen by Roland Emmerich. The following article will take a close look at émigré perspectives on American patriotism before and after 9/11.

\section{Independence Day:Denial of Democratic Gaps}

4 Emmerich's career as a director follows a path that suggests continuity with the escapist German film productions of the 1950s and 60s. Among his favourite directors, Emmerich sought out Horst Wendlandt, the producer of the highly commercially successful Winnetou trilogy (1963-65) based on the fictitious travel adventures in the Wild West of Karl May. Independence Day continues along the lines of using film as a medium to create fictitious accounts of an ideal "America." His reference to the campy western movies based on the escapist fiction of a nineteenth-century German writer already hint at the willingness to accept the confinements of the outsider perspective as the best basis for statements about the cultural "other." Emmerich creates a fictional scenario in which the United States and the "American dream" are figuratively destroyed in order to reaffirm its allegedly unconquerable spirit. The aesthetic trajectory of Independence Day follows a twofold agenda: first, it brings into perspective the American founding myths by translating the promise of renewal, regeneration, and rebirth encoded in the Declaration of Independence into contemporary science fiction films. At the same time, it offers the director a chance for recognition in the race for distinction in an American democratic environment. Hailed as "one of the most spectacular science fiction films of all time"' grossing more than $\$ 300$ million in the United States and almost half a billion in the rest of the world, Independence Day established "Emmerich" as a brand name for creating financial success at the American box office. ${ }^{7}$ The excessive celebration of American patriotism also earned the director an invitation by then president Bill Clinton to visit the White House for a private screening of his filmic "oath of allegiance." This must have been an even higher form of recognition than any ceremony of naturalization could ever hope to achieve.

5 In order to stage the ultimate fight between the United States and an outside aggressor, Emmerich relies heavily on one of the oldest formulas which go back to biblical stories. The deadly fight against the enemy follows along the lines of David and 
Goliath, the narrative pattern of an almost hopelessly inferior character who asserts himself against a superior power. With ingenuity and heroism, the underdog manages to outwit the enemy and thereby turns inferiority into superiority. The American president assumes the role of an action hero leading the battle against evil invaders as a bomber pilot. ${ }^{8}$ The fashioning of the American president into an action hero is in line with the visual narrative of American media history. As early as the Spanish-American war, Teddy Roosevelt led the "Rough Riders" and was documented in a dramatic way on celluloid. Although the footage was re-staged after the actual attack had happened, it set a new visual standard for how American presidents negotiate their public image with standardized representations of heroes. The representation of the president as an action hero calls to mind the successful blockbuster Air Force One directed by the German émigré filmmaker Wolfgang Petersen, released one year after Independence Day. Petersen recalled the lack of heroes in post-World War II Germany. American films filled a gap for young Germans growing up in Germany during the 1950s and 60s. ${ }^{9}$ When the Americans came to Germany to help in rebuilding the country, Petersen was deeply moved by the seemingly generous gesture of "help for self-help," the technical knowhow of American engineers, the skills of performance artists, and the popular culture they brought with them. "I have never forgotten that image of America," he later declared. "To us, America was something like a paradise."

6 The aesthetic transfer activated by seeing an American hero on the screen and the dream of becoming an American resembles a feedback loop from a German perspective. ${ }^{11}$ Petersen explains that the performance of Gary Cooper as Marshall Will Kane in High Noon (1952) left a deep impression on his youthful mind. The fact that he "wanted to be like Gary Cooper" was linked with the specific cultural situation of shame, destruction, and lack of models. Fred Zinnemann, the Austrian-born director of High Noon,had undergone a similar initiation when he became interested in American films during his student days in Vienna. Later he collaborated with directors Edgar Ulmer, Robert Siodmak, and Billy Wilder in Berlin, all of which fostered a career in Hollywood. Considering the international background of Hollywood directors, the fictional images of the American president cannot be separated from the fantasies of American heroes developed before coming to the United States..$^{12}$ What are the cinematic techniques employed by émigré filmmakers to celebrate the promise of American democracy?

7 Emmerich introduces his view on the United States with a powerful sign of approaching evil from the sky: an ominous shadow creeps slowly over familiar national landmarks. He concentrates on three American cities using images as if they are taken from a guidebook. The places depicted in New York City include the Statues of Liberty and the Manhattan skyline, panoramic shots of L.A. and the Hollywood sign, and sights of national memory in Washington such as the National Mall, the Capitol, the Abraham Lincoln Memorial or the Washington Monument. Independence Day is not interested in reshaping the collective imaginary relation to history and the American nation. Instead, its references to American national history function as sites to evoke the representative democratic nation created by "we, the people of the United States." ${ }^{13}$

III. 1: Travel guide to “America,"Independence Day 

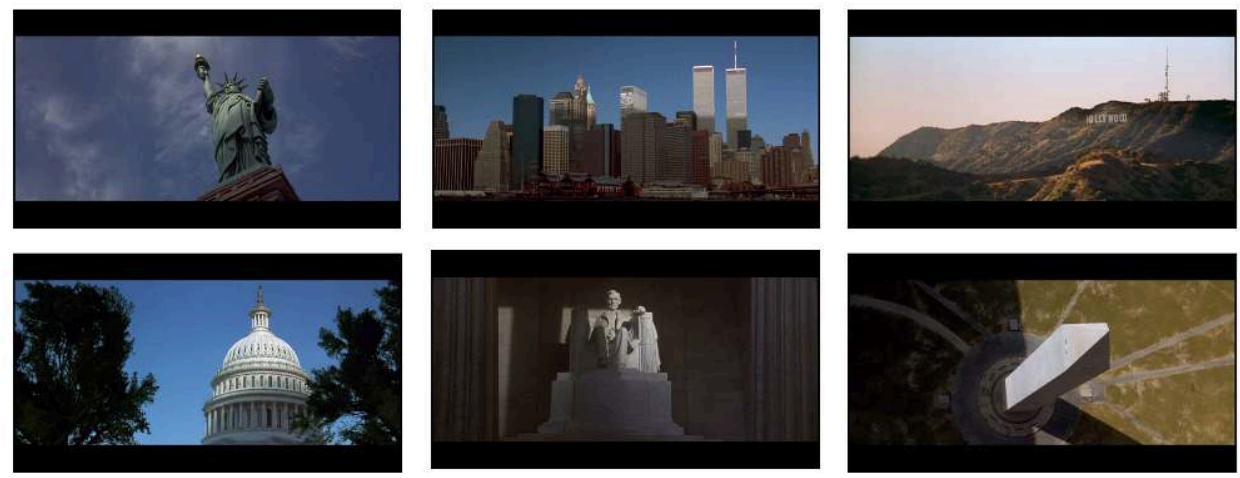

Visually, Emmerich uses these guidebook references to "America" only to destroy them in a hyper-real fashion. ${ }^{14}$ This plot device allows him to test the strength of the American founding myths and to affirm their values. The outside perspective of the German-born director offers a double mirror by reflecting the self-image which "America" has produced and promoted via cultural diplomacy since the European Reconstruction Program, better known as the Marshall Plan: the American nation as a beacon of hope and a democratic model for the whole world. This trajectory is as topical as ever. In the struggle against "evil" forces, America must lead as President George W. Bush remarked in his State of the Union Address of 2002 and "America will lead by defending liberty and justice because they are right and true and unchanging for all people everywhere." The assessment of the political theorist Michael Rogin that the film intensifies American World War II nostalgia due to a perceived "failure of Cold War victory to breathe new life into the United States" hardly pays attention to the outside perspective a German born director would bring to the issue of patriotism. ${ }^{15}$

III. 2: Global celebrations of the American military success, Independence Day
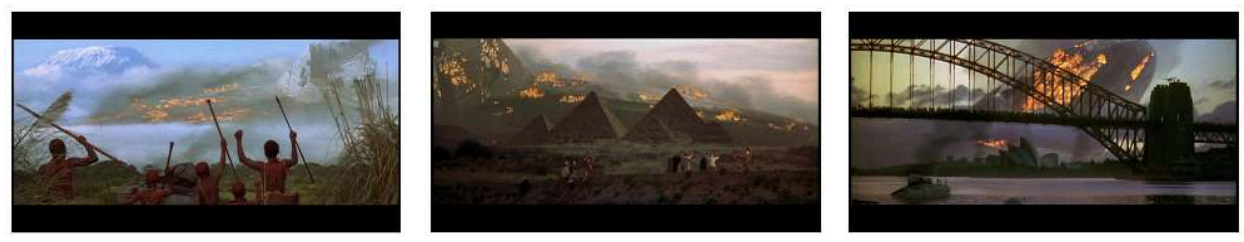

9 A good example of Emmerich's persuasive visual style to stir patriotism is the crucial presidential speech in which the American nation leads a coalition of nations from all over the world in the war against the alien invaders. Emmerich shows the American president in a combat suit improvising an address to his fellow fighters. Appearing as a primus inter pares, the scene is designed along the lines of an idealized patriotic American nation with a strong democratic missionary sense.

Mankind - that word should have new meaning for all of us today.

We can't be consumed by our petty differences anymore.

We will be united in our common interests.

Perhaps it's fate that today is the $4^{\text {th }}$ of July,

and you will once again be fighting for our freedom,

not from tyranny, oppression, or persecution -

but from annihilation.

We're fighting for our right to live, to exist.

And should we win the day, 
the 4th of July will no longer be known as an American holiday,

but as the day when the world declared in one voice:

"We will not go quietly into the night!

We will not vanish without a fight!

We're going to live on!

We're going to survive!"

Today, we celebrate our Independence Day!"

Emmerich designs the scene by effectively using reaction shots of those who listen to the presidential address. It is crucial to understand that the insistence on overcoming "petty differences" in the hour of oppression represents a declaration of independence for Mankind. However, the event takes place within the confinements of an American air base. The global perspective is based on a unilateral contract. The American myth of "Manifest Destiny" is alive and well in Emmerich's scenario of a worldwide Independence Day.

\section{3: Presidential Speech, Independence Day}
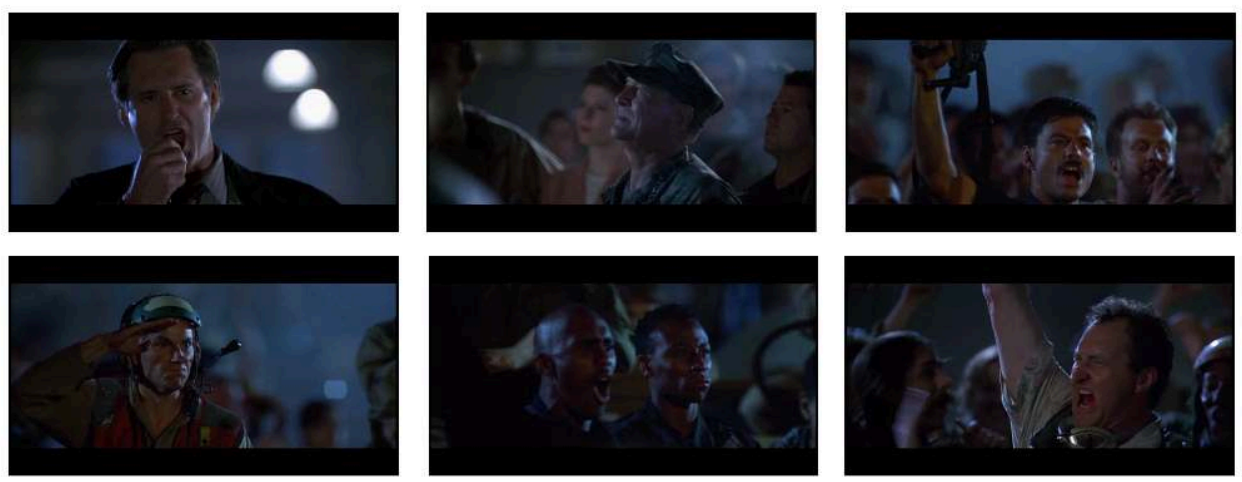

The emotional response of those who are persuaded by the passionate call for liberty include people with different ethnic backgrounds. In this moment, the mise en scène mirrors the American motto of $e$ pluribus unum visually in the presidential audience and their patriotic aspirations. What Michael Ignatieff calls "civic nationalism" is reflected in the patriotic cheers of the audience which becomes an image in nuce for the whole world in the fight for independence. ${ }^{16}$ The evocation of the American Independence Day is supposed to activate a global response: to share in a nationalism which envisages a global community of citizens who become united by the promise of "America."

12 The final scene is a fine example of translating notions of American patriotism into a glossy visual style. In the Utah desert, the war heroes meet with their families to reestablish the myth of the vastness of the American landscape ready to be re-cultivated, a renewal of the American civilization in a country where the president shares his rights of equality and liberty with the modern day settlers. The scene uses African Americans and Jews as representative citizens. The mise en scène in which the president and the heroic representative Americans appear is composed in a similar way adding to the fiction of a lived equality. The United States is re-affirmed as a place of cross-class communication and interracial harmony. 

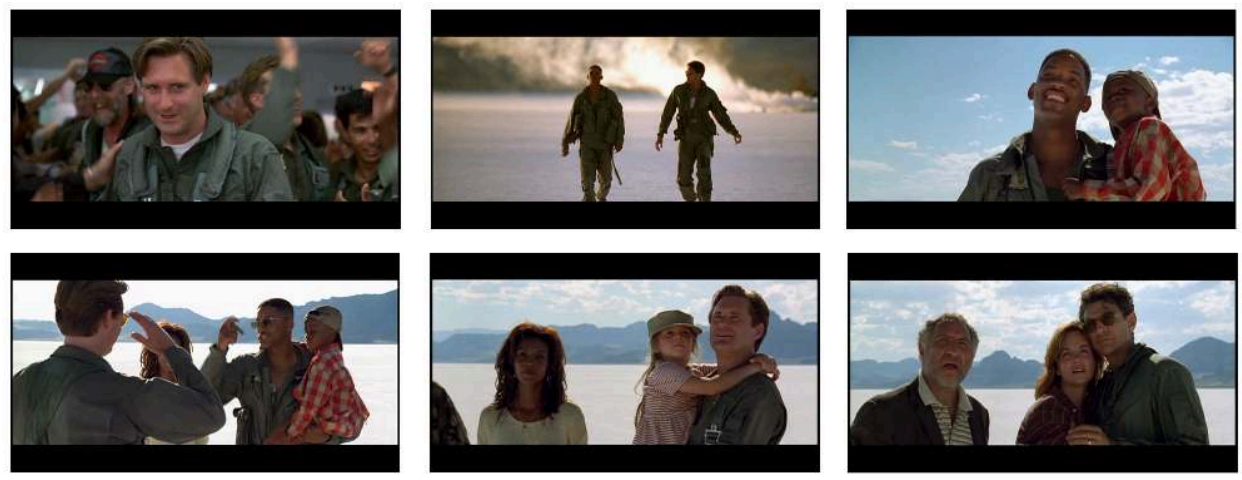

Emmerich's audio-visual response to the American democratic mission follows a specific pattern. The political theorist Samuel P. Huntington identified four response patterns to democratic gaps which are useful for the analysis of screening émigré patriotism. First, those people who tolerate the discrepancy between political theory and cultural practice engage in a cynicism. This attitude leads to the notion of moral helplessness. Second, those who ignore this democratic gap indulge in complacency showing no concern for American ideals or the need of political changes. Third, those who deny the gap exhibit a strong sense of hypocrisy seeing no discrepancy between American principles and practice. And fourth, those who are strongly committed to American values engage in political activism in order to bring about reforms. Emmerich's filmic response seems to follow the third pattern of denying the democratic gap. According to Huntingdon, this means that:

American institutions are seen to be open and democratic; America is the land of opportunity; the equality of man is a fact in American life; the United States is the land of the free and the home of the brave; it is the embodiment of government of the people, by the people, and for the people. During these periods, Americans so shape their perceptions that they cannot see any gap between the unpleasant facts of political institutions and power in the United States and the values of the American Creed. Reality is hailed as the ideal. The discrepancies are strained out and avoided. The United States not only should be the land of liberty, equality, and justice for all; it actually is. ${ }^{17}$

The film puts on a filtering lens to reaffirm the fantasy of "America." In light of the events of 9/11 and the American response, the film holds the potential for a postcolonial reading which turns the patriotic codes upside down. The allegoric formula of David against Goliath, which in the film applies to the United States against superior alien invaders, creates considerable problems when used as a foil to describe the "war against terror." The metaphors, symbols, and means to achieve independence could be interpreted as anti-American, as the United States resembles more the alien superpower while underdogs such as the black marine Captain Steven Hiller, the scientist David Levinson, or drunken ex-pilot Russell Casse function as Third World guerrilla forces. For example, the first flying saucer is detected over the desert of Iraq, which from today's perspective activates connotations of operation Desert Storm and the Iraq war. The heroic rebels fight the menacing colonizing forces from outer space by turning themselves into suicide bombers. This is true for Hiller and Levinson, who find themselves on a suicide mission to implant the deadly computer virus on the alien mothership. Quite literally, the final destruction of the alien invaders is caused by Casse 
flying his jet into the center of the ship. This self-sacrifice functions as a heroic deed in the cause of humankind. In light of the suicide bombers of $9 / 11$, the story offers the potential to be interpreted as an anti-colonial resistance to American world domination. ${ }^{18}$

15 Although written, produced and directed by a non-American citizen, the American public embraced and continues to enjoy Independence Day as an ultra-patriotic popcorn movie in the best sense of the term. The fantasy of the United States as the de-facto government of the world which re-unites mankind in a concerted struggle for freedom and independence harks back to the very founding myths of the New World. Particularly for American audiences, Emmerich provided a highly appealing exercise in showing "this is why they all love us!" 19

\section{Land of Plenty: Moralistic Response Patterns}

16 Wenders addresses the frustrating question many Americans asked themselves after the unilateral decision to wage a war on terror with a so-called "coalition of the willing:" why do they hate us? ${ }^{20}$ Shortly after Bill Pullman portrayed the American president in Emmerich's patriotic action extravaganza, Wenders chose Pullman in The End of Violence (1997) as the narrator for his view on paranoid fantasies of American culture being caught in a vicious circle of mass media and self-delusion. In contrast to Emmerich, Wenders activates another narrative formula which is by no means less popular in American mass culture: the fight of a modern day Don Quixote against the windmills as a parody of the David against Goliath theme. One of the two protagonists in Land of Plenty is Paul, a Vietnam Veteran who presents himself as a self-appointed homeland security agent. In his van equipped with second-hand surveillance equipment, Paul scans the streets of Los Angeles. In a pseudo-military jargon, he talks to himself and tapes his observations for future references. His perspective is clearly one of a delusional person trapped in an extreme system of fear of an invisible enemy. In the character of Paul, the power relations of superiority and inferiority are inverted. With his technological expertise and keen understanding of the enemy's weakness, he establishes himself as the superior agent in an ever-present state of civil warfare. However, it is clear to the audience that his excessive patriotism renders him blind in a fight against an imaginary enemy in which he cannot possible win.

17 Wenders shows Paul's extreme dedication to serving his country and his efforts to make the homeland safe against terrorist acts to reveal a side of nationalism which Tocqueville described as "irritable patriotism." ${ }^{21}$ The French aristocrat observed that foreigners are likely to provoke harsh reactions as not only the country but the nativist himself feels under attack. Despite the criticism of the Bush Administration's response to the terror attacks, leftwing critics deplored Wenders's naïve optimism and the metaphorical constructions of character development leading to a deeper understanding of the spiritual challenges after 9/11. Although the German émigré director taps into clichés of anti-Americanism such as the American dream betrayed, the land of disenchantment, the place of inequality and inequity, a people trapped in a vicious circle of materialism, there is a hidden agenda behind the agglomeration of disconcerting views on American culture.

18 Wenders's concept starts from a cynical point of view. Land of Plenty reveals the illusionary quality of the Hollywood dream factory. The first shot shows people 
through an infrared camera producing distorted colourful images. The production of patriotic images has led to an obsession with surveillance devices and frantic xenophobia. The second sequence deconstructs the movie title and mythic dream of a "Land of Plenty" by an extended drive through a ghetto of homeless people in Los Angeles. Wenders confronts the audience with shocking images of extreme poverty in what is usually hidden from the brand "America." This is a departure from The End of Violence (1997) in which the theme of American paranoia and violence in Los Angeles is conjugated within the image world created by the movie industry from the white Malibu beaches via the stunning infrastructure to the beautiful villas of media moguls.

III. 5: W. Wenders, Hunger Capital, Land of Plenty (2004)
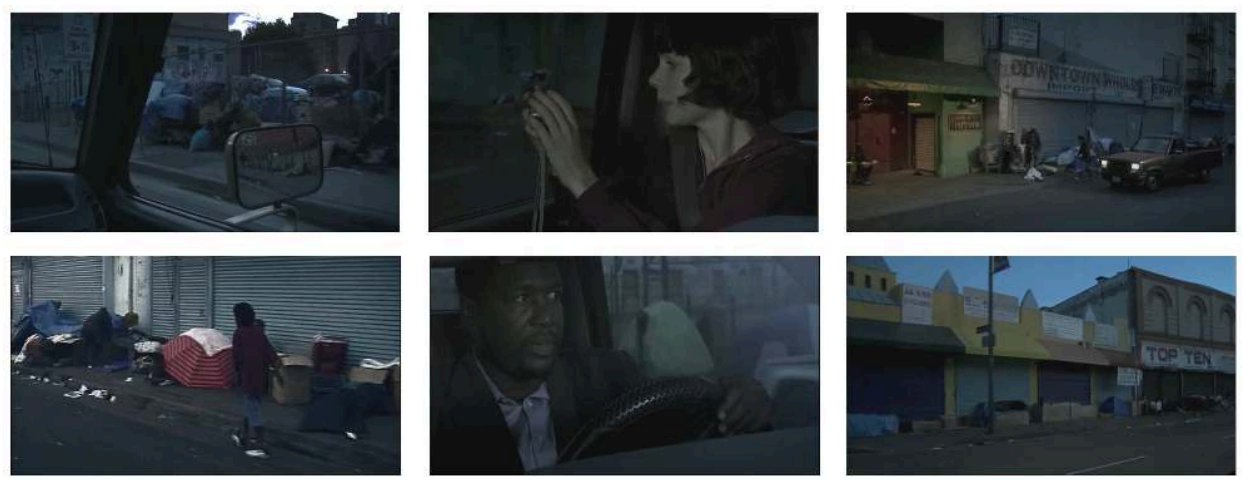

Beyond the familiar images of Beverly Hills, Hollywood and Sunset Boulevard lurks a dark side of the "American dream." Instead of the bright sunlit icons of American national history, Wenders offers sights at dusk. The murky images show homeless people living under miserable conditions surrounded by garbage. Through dialogue, the film locates the site geographically and emphasizes the cynical situation. "There are more homeless and hungry in Los Angeles than anywhere else in the States. This is the hunger capital of America," explains the African American priest. When Lana, a young girl from Israel, remarks that poverty was the last thing people talked about on the West Bank when they referred to "America," she starts an initiation process which many immigrants have undergone when their fictional image of "America" collided with the experience of reality. By using the medium of film, Wenders brings into perspective the falseness of the images generally associated with "America" as the "land of plenty." 22

Indeed, Wenders's title and the opening sequence may support the notion of a cynical look at the American promise of democracy. Land of Plenty starts with an observation camera and infrared images introducing the obsession with surveillance and stereotypical representations of the "other" via media. The scene is followed by a sequence displaying extreme poverty in some streets of Los Angeles. Showing the "American Dream" turned "American Nightmare" builds on stereotypical clichés of anti-Americanism. The German filmic tradition of "America" as dystopia goes back to Luis Trenker's Der Verlorene Sohn (1934) with its deploring documentary-style depiction of poverty and unemployment in New York City during the Great Depression. After 1945, American myths and their deconstruction were not so much part of an Ideologiekritik but driven by personal disappointments. During the 1970s and 
80s, the New German Cinema with Wenders's Alice in den Städten (1974) and Der Amerikanische Freund (1977), Werner Herzog's Stroszek (1977), or Volker Schlöndorff's Tod eines Handlungsreisenden (1985) exhibited German disenchantment by focussing on social inequity and crass materialism. The "war on terror" re-activated the creative potential of émigré directors to reveal democratic gaps in American culture. During several phases of his career, Wenders turned his back on the promise of an "America" full of disappointment and disgust. At a moment of crisis in the early 1980s, he blamed American films for covering up democratic gaps and the creation of (false) myths. A set of rhetorical questions charges the movie industry for his cultural misconceptions.

"Is it all dreamed out, the American dream?

Is somebody really still dreaming it,

or is it just the movies that keep it going?

Would it exist at all without the movies?

Is 'America' not an invention of the movies?

Would there be the dreaming of America, all over the world, without the movies? [...]

Is 'America' itself not the greatest projection?" 23

III. 6: W. Wenders, Drive-By shooting, Land of Plenty (2004)
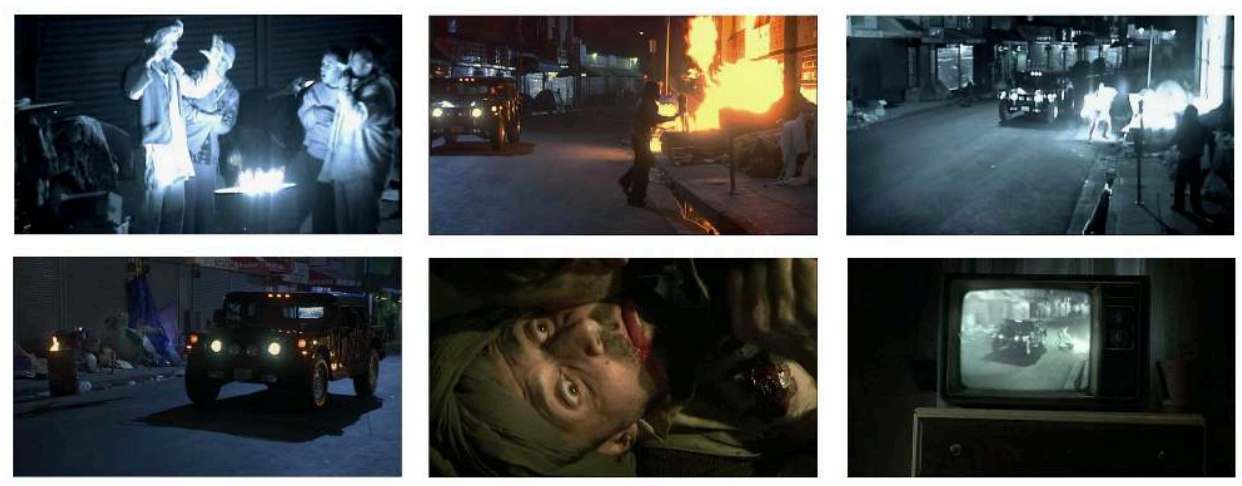

21 The drive-by shooting of an immigrant with a turban sets the plot in motion. As so often in Wenders's films, the filter of looking through cameras or looking at TV screens puts into question the substance and authenticity of what we see. This recurring theme in Land of Plenty sets the tone for the climactic scene when the protagonist enters the house of an alleged terror cell in Trona, California with night vision gear in front of his eyes. In a double mirror situation, the TV broadcasts President Bush's address in which he justifies the war on Iraq. When asked to switch the channel, the protagonist meets the request by a heavily charged metaphorical action. He hammers on the TV set and figuratively on his president's head. His scathing critique of the shortcomings of democratic expectations draws on what Samuel Huntington identifies as a form of political activism.

The moralistic response occurs when people feel intensely committed to American political values, clearly perceive the gap between ideals and reality, and attempt to restructure institutions and practices to reflect these ideals. ${ }^{24}$

Wenders creates stark contrasts between a newly-arrived person who talks, interacts with and helps the very people whom Paul only observes through his observation 
camera. Paul's perspective resembles a tunnel vision. His lens is calibrated to perceive (imaginary) signs of criminal energy against the American system. The filter of the screen image distorts his perception of his environment. Wenders pushes this distortion to further extremes when Paul is in full gear with infrared glasses to destroy the terrorist enemies. In this sequence, Wenders finds the ultimate metaphor to visualize how the media informs the perspective on the world around us. In turn, Wenders deconstructs the very medium which has been utilized to present the "war on terror" as a counter-sedative. ${ }^{25}$ The film reflects the anger of a dedicated Americanophile whose dream of "America" has been hijacked. In his critical commentary on the home-video edition of Land of Plenty, he gives vent to his irritation caused by the Bush Government.

A war-hungry government which wages war on the back of the poor in the country and undermines every notion of truth with ever more shameless and unbearable lies - this could not be harmonized with the Christian spirit. As a German and a Christian believer living in the United States, I had the notion that the country had been hijacked. Our film deals with the consequences of this kidnapping of American ideals and the perversion into their opposites."26

III. 6: W. Wenders, Infiltrating the "terror cell," Land of Plenty (2004).
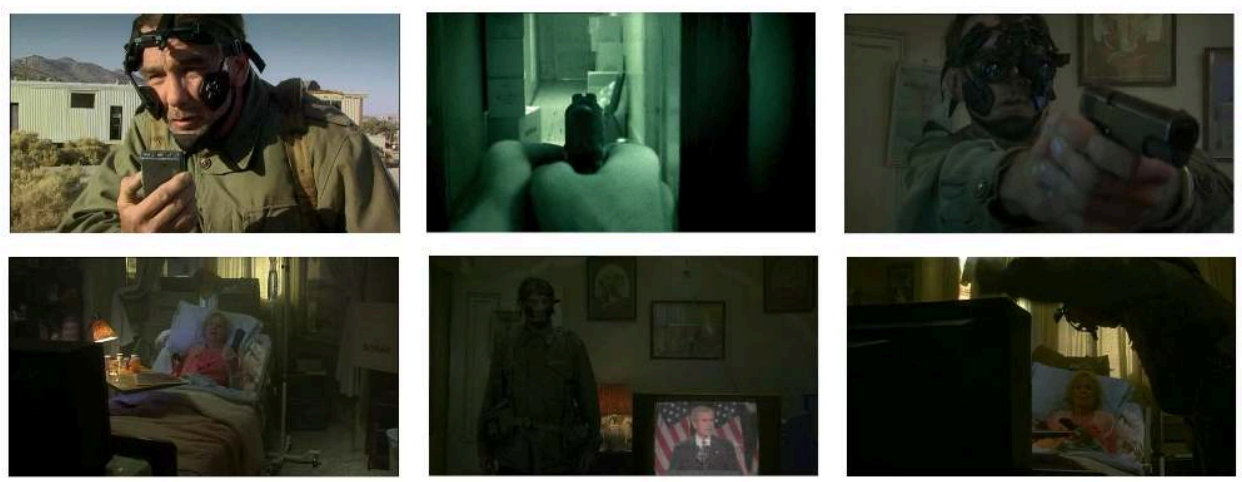

As the ambiguous title Land of Plenty indicates, Wenders deals with his conflicting notions of "America" and the clash between the cultural imaginary and the actual experience. In his prose poem "The American Dream" (1984), Wenders explained that he had envisioned the United States as a "land of plenty" in a double sense: land of material wealth and a set of abstract signs which held the promise of inspiration and enlightenment. "I saw America as the country where vision was set free." ${ }^{27}$ This notwithstanding, the "land of the free" and the "land of unlimited opportunities" turned out to be an illusion spurred by the medium of film. His urge to fashion himself into an American was particularly intense. Upon his arrival in the "promised Land," Wenders had an epiphany which he shared with many immigrants of earlier generations: the feeling of finally "coming home." The experience of alienation marks one of the driving forces to constantly work towards breaching the rupture between ideal and reality.

My first time in AMERIKA

I rode into Manhattan one morning,

crack of dawn, on the bus

from Kennedy airport.

I was HOME. It's the only way I can describe how it felt

that day, when, from dawn to dusk, 
I walked the streets,

stepping in every puddle and every heap of dogshit,

because all the time I was looking upwards.

However new it all was, it already seemed familiar:

this one city contained and revealed

all the other cities I knew. ${ }^{28}$

How did the American audience respond to Wenders's ideological critique after 9/11? In the United States, Wenders has made a career of providing alternative perspectives on American culture and deconstructing the "American dream" as a nightmare. Surprisingly, even leftwing critics have responded unfavourably to his attack on American patriotism in Land of Plenty. In the remaining part of this chapter, I will offer an explanation and analyze the cinematic translations of the German cultural imaginary which caused such irritation among American audiences.

In order to understand the reaction, it is crucial to bring to mind the ideological basis on which the remarkably positive reception of Wenders's films of the 1970s and 80s rests. Wenders and the New German Cinema filled a gap in German cultural history. At the same time, American intellectuals, who tried to come to terms with the traumatic events in Vietnam, used the critical outside perspectives as a source of inspiration. Film historian Eric Rentschler described the inter-cultural nexus at the height of Wenders's popularity in the US in 1984:

[New German Cinema] continues to scintillate and galvanize at a moment when the American public seriously confronts the ever-present possibility of doom and destruction. In the nightmare visions of New German Cinema, its gripping tales of angst and disaffection, one finds expressions of a fearful modernity and a worldwide disenchantment rarely presented by America's either overly sanguine or blatantly cynical dream factory. ${ }^{29}$

The films Wenders directed during his first extended sojourn in the United States have been categorized under three groups in order to come to terms with the disappointment regarding the shortcomings of the "American dream." All of these categories root the response in the specific German cultural experience after World War II. The first approach follows the thesis of cultural imperialism as an object of criticism. The Marshall Plan with its promise of political stability and economical wealth for a democratic Western Germany has given way to a sense of materialism and a sense of potential doom brought about by an ever more aggressive foreign politics, particularly in the context of the Vietnam War. The second approach refers to a "lovehate-syndrome" in order to emphasize the function of "America" as an Ersatz homeland for a fatherless generation of young German artists. American culture activated fantasies of the democratic "other" beyond the Atlantic. For many of those who had travelled and lived for some time in the United States, the transatlantic experience became simultaneously a source of enchantment and disenchantment. The third approach interprets the films as a way to deal with historical amnesia by emphasizing the escapist tendencies in the fictitious notions of "America." With the traumatic heritage of World War II, the memories of fascism, and genocide, German directors imported their inner conflicts into the American cultural scene.

What kind of new elements offer a perspective on the "Land of Plenty" after 9/11, which seem to be disconcerting to American intellectuals? ${ }^{30}$ Let's take a look at the review of the New York Times critic A. O. Scott. He identifies Wenders as a national and cultural outsider who intervenes in intimate American affairs. Scott emphasizes 
Wenders's transatlantic roots to deconstruct the film as naïve. While acknowledging the German-born director's dedication to American culture, Scott sees his view is almost by definition "romantic and always affectionate." He continues:

Taking up the divided, anxious state of post-9/11 American life, Land of Plenty ... is like a clumsy, well-meaning intervention in a family quarrel. Mr. Wenders may not have the power to heal the rifts his movie acknowledges - and his account of them may not always be persuasive - but there is nonetheless something touching about his heartfelt concern. ${ }^{31}$

The language of the review establishes a hierarchy between the knowledgeable insider and the naïve outsider, between nativist and foreigner. ${ }^{32}$ In his conclusion, Scott charges Wenders with staging a fantasy which is all too idealistic and patriotic:

"[Land of Plenty] insists that expressions of caring and sympathy, even if they risk mawkishness, are the best available antidotes to hatred and intolerance. It is as hard to argue with this idea as it is wholeheartedly to believe it completely." ${ }_{33}$

For leftist cultural critics, Wenders did not live up to expectations. This is a surprising response to a film that shows the ugly side of poverty in Los Angeles, urban sprawl, deserted villages, people out of touch with their environment and traumatized by a history of imperialistic wars.

The final sequence in particular has caused irritation among critics as being saccharine and artificially constructed. Wenders celebrates images of the American West with its open and vast landscapes familiar from American photographers and guidebooks. In the spirit of the 1960s and shot in road-movie style, he has the protagonists criss-cross the country in their run-down van with a battered American flag attached to the rear. The sequences seem to move away from the harsh criticism of the constructed media images to perpetuate the "American dream." The stylized images return to the evocation of an "America" Emmerich introduced by his depiction of pristine national landmarks gleaming in the sun before the (alien) attacks.

31 In the physical and literal approach of Wenders's protagonists to Ground Zero, the musical subtext is of particular importance. The soundtrack functions like a director's commentary from off screen. Leonard Cohen's duet with Sharon Robinson, also called "Land of Plenty," fills the silence between the two protagonists. The music brings a spiritual quality to the quest for truth which reverses the myth of Manifest Destiny. Instead of travelling westward, the modern-day "Searchers" (in the sense of John Ford's film of the same title) go back to the beginning of the American history of settlement. Wenders carefully selected the lyrics by Leonard Cohen to function as a poetic mirror of his own state of mind as an Americanophile transatlantic traveller. ${ }^{34}$

Don't really know who sent me

To raise my voice and say:

May the lights in The Land of Plenty

Shine on the truth some day. ${ }^{35}$ 
III. 7: W. Wenders, 1960s travel guide to "America" from Land of Plenty (2004)
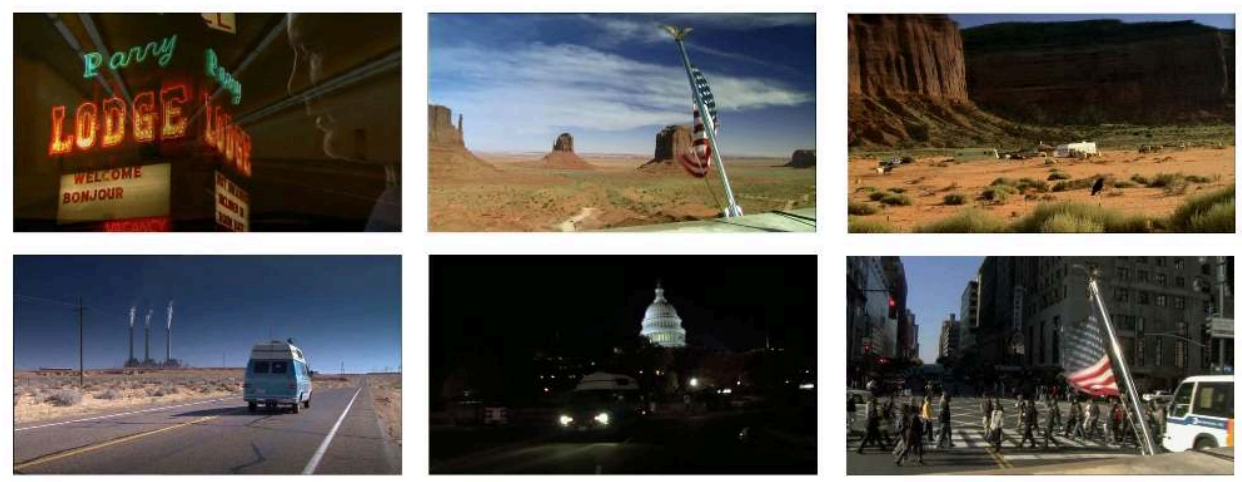

32 The final scene at Ground Zero offers hope and redemption for Paul's failure to understand what is at stake in his country after 9/11. Lana as the cultural-outsiderturned-insider (who functions as a kind of doppelgänger for Wenders) shows Paul the appropriate way to respond to the rupture created at Ground Zero. They close their eyes to listen to what this particular space might have to tell him. Wenders's images emphasize the healing powers which reside in the American people and their history. Through the act of closing one's eyes, Wenders counter-balances what he identified before as an American patriotic blindness. Other senses need to be activated and sensitized. The addiction to sights and ideological filters in the act of seeing has led to a lack of vision. In order to understand the reasons, symptoms, and potential answers to the site of Ground Zero, familiar ways of apprehension need to be unlearned, changed, and put to better use than before.

III. 8: W. Wenders, sound senses at Ground Zero, Land of Plenty (2004)
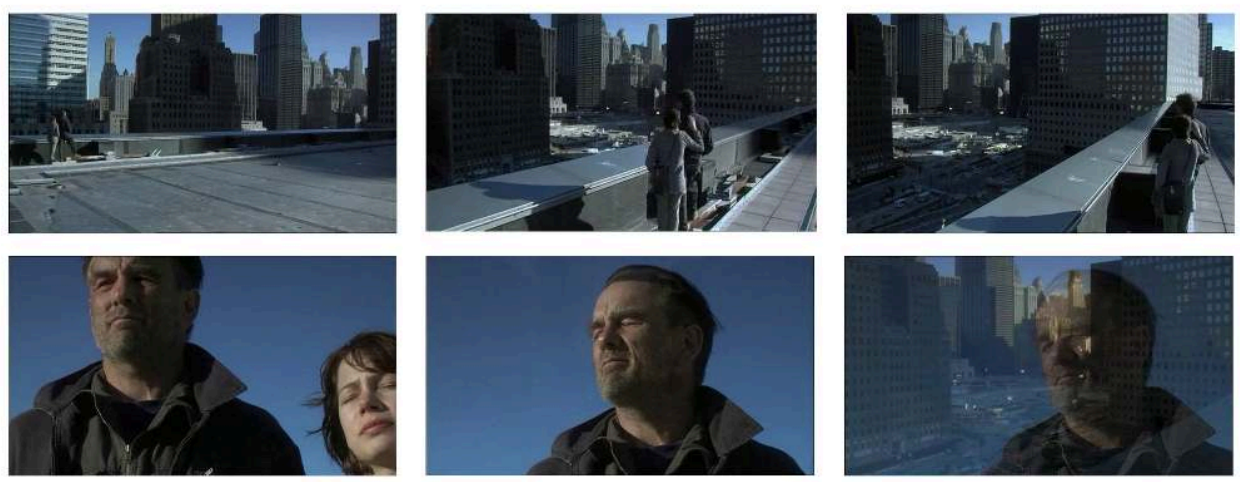

The sequence at Ground Zero does not so much resemble a break in the narrative from uncovering lies and imaginary constructions of the "Land of Plenty." Instead, there is a constant move from the ugly side of "America" to the potential of what "America" could be from an outside perspective. Even the scenes of great despair such as Paul's mental breakdown after his delusionary war on the alleged terror cell outside of Trona, draw on the very images, which resemble archetypes of "America." For example, Wenders shows Paul wandering off alone into the twilight of the desert. The quotation from the quintessential American western The Searchers (1956) by John Ford activates memories of the hero as a broken character. Like a mirror, Wenders reflects the myth of the western hero in the rites of initiation Paul must undergo after his failed attempt 
to "secure the homeland." The female character departs in a similar way on her own quest for truth. Before both of them are prepared to face the space of Ground Zero, Wenders puts them into situations of quiet despair. Again, what appears to be criticism of the "American dream" activates the very iconography which perpetuates the belief in the beauty and healing powers of "America." For example, the sequence in which Paul and Lana spend the night in a hotel seems to undermine the glorious selfperceptions of Americans. The sequence shows a breakdown of communications. Paul suffers from post-traumatic stress haunted by a recurring nightmare about his time as a soldier in Vietnam. Silently, Lana uses her computer to get in contact with her friends from Palestine while feeling lost in the American middle of nowhere. The mise en scène with Paul in the foreground in his bed and Lana in the backroom projects a pervasive strong sense of loneliness and despair.

III. 9: W. Wenders, modern day "searchers," Land of Plenty (2004)
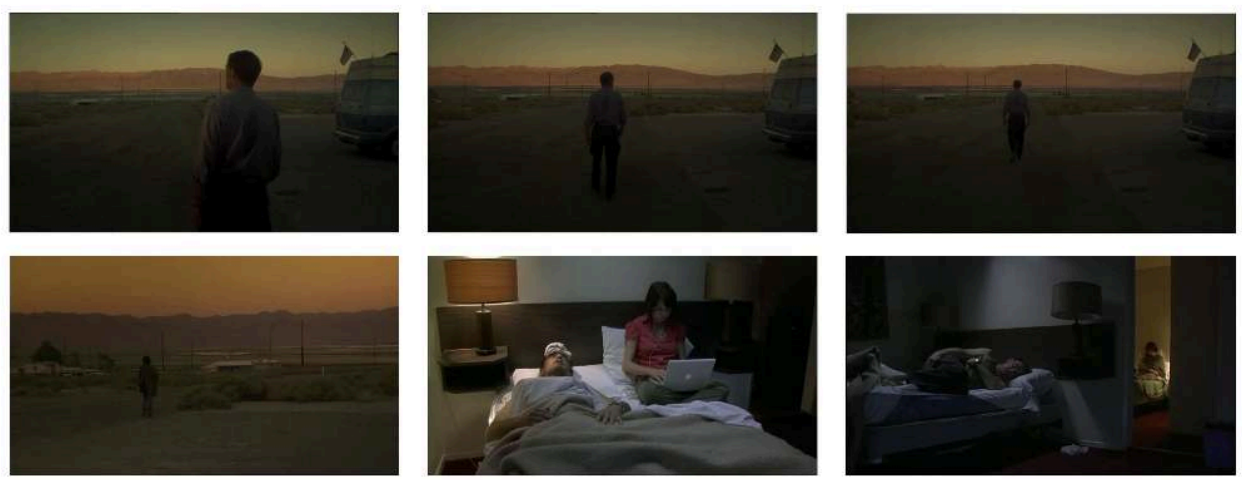

Despite the negative connotations, these sequences are aesthetically pleasing. A comparison with the aesthetic impact of the paintings of Edward Hopper might shed light on the opposing forces at work in Land of Plenty. Wenders utilizes aesthetic techniques which dominate the paintings of the very American artist whom he most admires. Hopper has been identified as an artist who successfully shows the audience the other side of the American dream by focussing on loneliness, isolation, miscommunication, and anonymity. At the same time, the worldwide appeal of Hopper paintings suggests that the suppression of a truthful image beyond the glossy surfaces of the "American dream" has its own appeal. Winfried Fluck has shown that the inherent cultural critique cannot be the only explanation for the strong emotional responses Hopper's iconographic "America" produce. "The fascination of Hopper's paintings, then, does not lie in their being 'Portraits of America' (Wieland Schmied) or their deconstruction of the American dream or in a critique of the American way of life," he writes, "but in a redefinition of the drama of subjectivity." ${ }_{36}$ Hopper's characters often appear self-contained in their self-imposed silence, thereby counterbalancing familiar tropes of obsessive optimism commonly associated with American culture. Hopper's paintings tell of a search for truth beyond the media iconography. A similar quest inspired Wenders's Land of Plenty, asspelled out explicitly in the subtitle of the German release version not used in the American original: "Die Suche nach Wahrheit" ('The Quest for Truth')." In addition, the sequence depicting poverty and crime in L.A. ghettoes activates visual patterns which have been immortalized by the famous photographers Walker Evans and Dorothea Lange. This iconography created for the Farm Security Administration in the mid-thirties has 
entered the public consciousness and determines the shared visual history of the depression era. For many intellectuals and scholars, they function as documents of the “"truth' about America." ${ }^{37}$ The quest for "truthful images" which Wenders thematizes in Land of Plenty derives its powerful aesthetic impact from the dream of subjectivity in response to 9/11. Land of Plenty suggests a re-enchantment with "America" - a sense which also pervades Wenders's post-9/11 films shot in the United States such as The Soul of a Man (2003), 12 Miles to Trona (2003), or Don't Come Knocking (2005). ${ }^{38}$

\section{Conclusion}

35 Emmerich's utopian Independence Day offers a cinematic translation of civic nationalism into a science fiction adventure. The German-born director combines elements of American soft power and public diplomacy of the European Reconstruction program, from which Western Germany profited substantially, to fashion himself into a representative American. The United States appears as a democratic beacon for all Mankind following a response pattern based on denial of the democratic gap. Wenders comes from a similar transatlantic cultural background. However, he offers a gloomy counter-narrative to the American promise of democracy. Wenders draws upon our cultural memory of films, photographs, and paintings to combine cultural criticism with a re-affirmation of the potential of an imaginary democratic "America." Like Hopper, his use of space, light, color, and the position of his protagonists offer a highly stylized version of an imaginary "America."

36 The persuasive promise of American democracy and the founding myths continue to haunt the imagination of Germans. However, since the mid-twentieth century, the acquisition of American citizenship has lost its appeal for intellectuals as a means to fashion themselves into Americans and to gain recognition. Instead, a new generation of what might be called transatlantic Germans with cosmopolitan aspirations have developed an ambivalent perspective on American culture. The work of Roland Emmerich and Wim Wenders exemplifies the spectrum of approaches to negotiate the fantasy of, desire for, and experience of American culture in the medium of film. Emmerich works within the confinement of American genres in close collaboration with major Hollywood studios and has earned the reputation of being a patriotic American director par excellence. Wenders, in contrast, has freed himself from the selfinflicted burden of becoming an "American" director. Instead, he ventures freely between his homes in Berlin, New York, and the United States. His "American films" are produced entirely by German companies.

37 Thus, we have come to a surprising conclusion in comparing two unlikely contenders in the display of American patriotism from an émigré perspective before and after 9/11. Ultimately, Land of Plenty represents the flipside of one medallion with Emmerich's Independence Day on the other. Both versions of the "American dream" draw on the persuasive power of fiction to reaffirm the American promise of democracy, equality, and the pursuit of happiness. Wenders's moralist response is in line with intellectual émigrés who engaged in what I call a patriotism of dissent. This form of activism produces a paradoxical situation. While using dissent to reaffirm the belief in the great potential of the American experiment, the founding myths, and the democratic promise, Americans disqualify the patriotic statement as a naïve intervention from an alleged cultural outsider. The transnational arena in which 
Emmerich and Wenders screen American patriotism exemplifies the need of the fictional construction of a democratic America. Even in the catastrophe of 9/11 lie the seeds for a re-enchantment with "America."

\section{BIBLIOGRAPHY}

\section{Filmography}

\section{Films by Wim Wenders:}

Alice in den Städten. Dir. Wim Wenders. West Germany, 1974.

Der Amerikanische Freund. Dir. Wim Wenders. West Germany and France, 1977.

The End of Violence. Dir. Wim Wenders, United States, 1997.

The Million Dollar Hotel. Dir. Wim Wenders. United States, 2000.

The Soul of a Man. Dir. Wim Wenders. United States, 2003.

12 Miles to Trona. Dir. Wim Wenders. United States, 2003.

Don't Come Knocking. Dir. Wim Wenders. United States, 2005.

Land of Plenty. Dir. Wim Wenders. United States, 2004.

Films by Roland Emmerich:

Independence Day. Dir. Roland Emmerich. United Sates, 1996.

The Patriot. Dir. Roland Emmerich. United Sates, 2000.

Other Films mentioned (in chronological order):

Roosevelt's Rough Riders. United States, 1898.

Der Verlorene Sohn. Dir. Luis Trenker. Germany, 1934.

Why We Fight. Dir. Frank Capra. United States, 1943-45.

High Noon. Dir. Fred Zinnemann. United States, 1952.

The Searchers. Dir. John Ford. United States, 1956.

Stroszek. Dir. Werner Herzog. West Germany, 1977.

Tod eines Handlungsreisenden. Dir. Volker Schlöndorff. United States and West Germany, 1985.

Glory. Dir. Edward Zwick. United States, 1989.

JFK. Dir. Oliver Stone. United States, 1991.

Thunderheart. Dir. Michael Apted. United States, 1992.

Born on the Fourth of July. Dir. Oliver Stone. United States, 1989.

Malcolm X. Dir. Spike Lee. United States, 1992.

Forrest Gump. Dir. Robert Zemeckis. United States, 1994. 
Jefferson in Paris. Dir. James Ivory. United States, 1995.

Air Force One. Dir. Wolfgang Petersen. United States, 1997.

\section{NOTES}

1. Not surprisingly, Wenders has received great attention from film scholars and cultural critics. Particularly after his latest phase of being a filmmaker in the United States, research projects on his multimedia oeuvre have flowered with a special emphasis on transatlantic and intermediary questions. Among the more recent publications are Horst Fleig, Wim Wenders: Hermetische Filmsprache und Fortschreiben Antiker Mythologie (Bielefeld: Transcript, 2005); Volker Behrens, ed., Man of Plenty - Wim Wenders (Marburg: Schüren, 2005); Giovanni Spagnoletti, Lineamenti introduttivi alla storia del cinema: il nuovo cinema tedesco; Rainer Werner Fassbinder e Wim Wenders (Rome: Aracne, 2004); Stefania Ricci, Off Scene: Wim and Donata Wenders (Florence: Pagliai Polistampa, 2004); Carlo Avventi, Mit den Augen des Richtigen Wortes: Wahrnehmung und Kommunikation im Werk Wim Wenders und Peter Handkes (Remscheid: Gardez!, 2004); David Coury, The Return of Storytelling in Contemporary German Literature and Film: Peter Handke and Wim Wenders (Lewiston: Mellen Press, 2004); Alan Keele, In Search of the Supernal: PreExistence, Eternal Marriage, and Apotheosis in German Literary, Operatic, and Cinematic Texts (Münster: Agenda, 2003); Matthias Ganter, Wim Wenders und Jacques Derrida. Zur Vereinbarkeit des Filmschaffens von Wim Wenders mit Jacques Derridas Dekonstruktiver Literaturtheorie (Marburg: Tectum, 2003); Alexander Graf, The Cinema of Wim Wenders: The Celluloid Highway (London: Wallflower Press, 2002).

2. Dissent challenges unjust hierarchies and fosters change. The imaginary America as a land of freedom rests on the conviction that the First Amendment to the United States Constitution guarantees freedom of speech for everybody. Whenever the decision-making process violates the pattern of free discussion, weighing of arguments, and compromise, dissent needs to be voiced. By the term "dissent," I mean those texts and speech acts (in the widest sense) that criticize existing authorities, institutions, traditions, and customs. Socio-political activities created force fields of conflict. They have emerged throughout American history. Striking examples include the abolitionist activities of the socalled "48ers" and their fight for female emancipation in the antebellum era. Later, in the second half of the nineteenth century, intellectual émigrés insisted on the multilingual heritage and ethnic diversity of the United States. In the wake of two World Wars, many resisted neo-colonial distinctions for citizenship, voiced criticism regarding unrestricted capitalism, and shed light on economic exploitation, crass materialism, political self-righteousness, and tendencies of cultural imperialism in the twentieth and twenty-first century.

3. "Back in the US of A," in Daniel Bickerman, ed., Wim Wenders: A Sense of Place. Texte undInterviews (Frankfurt am Main: Verlag der Autoren, 2005), 227.

4. Interview with Jakob Buhre, "Wim Wenders: Hauptberuf Reisender," http:// planet-interview.de/wim-wenders-21092001.html[accessed 28 June 2008]. Unless otherwise indicated, all translations from German into English are my own. 
5. Emmerich proudly mentioned his all-time record of seeing Winnetou three times in a row. The statement is revealing regarding two aspects which continue to be central in Emmerich's cineastic driving forces: financial success and the allure of larger than life scenarios. See the interview with Emmerich in Jo Müller, Roland Emmerich: Eine Werkbiografie (Cologne: vgs, 1998), 20.

6. Keith M. Booker, Alternate Americas: Science Fiction Film and American Culture (Westport and London: Prager, 2006), 233.

7. In a review in Variety, film critic Todd McCarthy quipped about the nexus of American patriotism and émigré film directors. "It took a foreigner to create what could arguably be the most patriotic film since John Wayne rode into the sunset." See http://www.variety.com/review/VE1117905388.html? categoryid $=31 \& c s=1 \&$ query $=$ independence + day $\&$ display $=$ independence + day [accessed February 2008].

8. Robert Burgoyne points out that some Hollywood feature films contest the foundational narratives of the nation. Films such as Glory (1989), Thunderheart (1992), JFK (1991), Born on the Fourth of July (1989), Malcolm X (1992), Jefferson in Paris (1995), or Forrest Gump (1994) focus on narratives of American national history to explore the meaning of "America" from a perspective which earlier films had allegedly largely ignored. Thus, they provide a counterpart to what sociologist Jacques Rancière's identified as "dominant fiction." Burgoyne remarks that "many of the most hallowed myths of nation have been challenged and criticized in feature films that contest the basic premises of American ideology" - the myth of manifest destiny, for example, or of the progressive extension of liberty to ever-increasing numbers of people, or of the power of national belonging to displace the lived identity or race, or of the existence of a single, homogeneous nation extending from "sea to shining sea." See Robert Burgoyne, Hollywood Looks at US History (Minneapolis: University of Minnesota Press, 1997), 7. Emmerich's Independence Day goes in the opposite direction. He draws on the memory of propaganda films such as Frank Capra's Why We Fight,Bmovies of the 1950s, as well as the American blockbusters Star Wars (1977) and Close Encounters of the Third Kind (1977) which in turn also draw on World War II movies and early genre films. Compared to his American colleagues, such as directors Steven Spielberg, George Lucas, or Richard Donner, Emmerich's "genre memory" (Bakhtin) is filtered through a specific German lens. Emmerich grew up after World War II in a south German cultural context in which American movies became a soft power to feed the collective imaginary of what "America" stood for and promised. In the German national context, the American promise and dedication to concrete action became manifest in the Marshall Plan, the Berlin air lift, the survival of West Berlin as a part of Western Germany, and to a certain degree the commitment to envisioning a "New Europe" with Germany as an integral part.

9. The medium of film represents one of the most important currencies in the flow of information and discourse on American patriotism making it possible to trace back different functions of screening American patriotism from a German émigré perspective. Images, sounds, objects and commentaries within a tight national narrative of public diplomacy can acquire ambivalent meanings in the 
process of translation and appropriation in another culture context. Joseph S Nye, Jr. argues that these elements of American culture are so-called "soft power." Efforts to convey a certain (positive) image of "America" are concerned with the relation of information and power. The US finds itself in a competitive situation in which the goals and benefits for both sides need to be communicated. The difference between asymmetrical situations, the world of trade and information, is striking. In economic terms, power "goes to those who can afford to hold back or break trade ties, power in information flows goes to those who can edit and authoritatively validate information, sorting out what is both correct and important." Official actions and indirect ways to exercise power involved the United States Information Agency, the Voice of America, the Fulbright program, American libraries, lectures, and other cultural programs. This kind of "soft power" should generate a "demand in other people's minds for something you want to have." (Joseph S. Nye, Jr., The Paradox of American Power: Why the World's Only Superpower Can't Go It Alone [Oxford: Oxford University Press, 2002], 67, 70.) However, the demand is created only partly by the American government. More often than not, unintended effects evolve despite of it. Soft power can thus create both attraction and repulsion.

10. The interview was conducted by Rick Lyman. "Watching Movies With Wolfgang Petersen; A Boy Shaped by High Noon," New York Times, 20 March 2001). See http://query.nytimes.com/gst/fullpage.html? res $=9$ C01E2DA143FF933A05750C0A9679C8B63\&scp $=1 \& s q=$ watching + movies + with + wolfgang + petersen\&st $=$ [accessed 15 March 2008].

11. In his book-length analysis of Independence Day Michael Rogin explains that Emmerich (and his co-writer Dean Devlin) "locate their 'collective unconscience' entirely within movies." See Michael Rogin, Independence Day (London: British Film Institute. 1998). However, he hardly addresses the deeper structures of cultural translation, patterns of creative appropriation, and the ambiguous functions which American escapist films played for a director growing up outside of the American way of life in postwar Germany. See in this context for example Christine Haase's analysis of German émigré directors. For example, she argues that Emmerich's use of and reliance on clichés in American genre films marks him as a provider of an outside perspective. See Christine Haase, When Heimat Meets Hollywood: German Filmmakers and America, 1985-2005 (Rochester, NY: Camden House, 2007), 101.

12. Petersen links his career in Hollywood explicitly to the fantasy of American heroes and political leadership from the perspective of growing up in post-World War II Germany. "You know, when you grow up and when no one around you seemed to care, where it was all about making money and rebuilding Germany and being ashamed and silent about the past, a movie like this [High Noon] can have such an effect on a young man. ... This movie had such an enormous impact on me because I could see what a story can do to you, how it can change your perspective. It was not just entertaining. I was deeply moved by it. And now, here I am, sitting with you on this Hollywood lot, and I am making movies." "Watching Movies With - Wolfgang Petersen," op. cit.

13. See http://www.whitehouse.gov/news/releases/2002/01/20020129-11.html [accessed on 18 January 2008].

14. The alien invasion follows an aesthetic concept of shock and awe. The superior firepower of highly developed weapons combined with a surprise attack acquires a sense of ethereal beauty. In the race for what Umberto Ecco called 
"hyperreality," Independence Day sets a new record in adding more and more layers of details to celebrate the beauty of destruction. The gigantic alien spaceships fly, for example, towards the World Trade Center, hovering over the White House or the Empire State Building before they unleash their destructive force in a fireball.

15. See Rogin, Independence Day, 17. In a talk delivered in 2009 , Robert Pirro made a convincing argument that one can detect themes of German wartime suffering and the hopes related to the German reunification in 1989 which are encoded in the visual iconography of Independence Day. Turning to Günter Grass's novel, Im Krebsgang (2002) and W.G. Sebald's essay on the postwar German literary response to the Anglo-American bombing of German cities, Luftkrieg und Literatur (2001, appearing in English in 2003 under the title, The Natural History of Destruction), Pirro shows the correlation between notions of victimhood and impulses of post-unification German culture. He argues that "[h]owever inadvertently these elements were formed by Emmerich and the many German collaborators on his blockbuster, they resulted in a film that could afford German audiences the opportunity to revisit the formerly taboo subject of (non-Jewish) German wartime suffering in problematic ways." Quoted from an unpublished manuscript based on Pirro's talk "Luftkrieg and Alien Invasion: Unacknowledged Themes of German Wartime Suffering in the Hollywood Blockbuster Independence Day" delivered as part of the Perspectives on American Literature and Culture series on 16 July 2009 at the John F. Kennedy Institute for North American Studies, Berlin.

16. Michael Ignatieff, Blood and Belonging: Journeys Into the New Nationalism (New York: Farrar, Straus and Giroux, 1994), 1.

17. Samuel P. Huntington, American Politics: The Promise of Disharmony (Cambridge, Mass. and London: Harvard University Press, 1981), 70.

18. While M. Keith Booker is right to emphasize that "the aliens as inhuman Others [are] unworthy of sympathy," the references to an anti-colonial allegory become more important when the perspective shifts to that of the alien invaders. A simple formula of good versus evil in the guise of David against Goliath might hold a subversive narrative based on the critique of colonialism triggered by unforeseen events in the real world. It remains to be seen how persuasive a reading of Independence Day as a critique of colonialism might be. Booker, Alternate Americas, 245.

19. If a real president were able to borrow the persuasive power of the film hero, he would be at a vantage point. Not surprisingly, the media event of declaring victory in the so-called "war on terror" used Hollywood images as a foil. Emmerich's fictional attack on New York City had rendered the actual news footage of 9/11 on CNN as if it had been a science-fiction disaster film. The response of the fictional United States with the American president flying an F-16 to free the world from oppression set the standard for the way George Bush embarked from an F-18 Hornet in a bomber pilot uniform on the aircraft carrier USS Abraham Lincoln to announce that Iraq was free. "In this battle, we have fought for the cause of liberty and for the peace of the world. Our nation and our coalition are proud of this accomplishment." 
http://www.cnn.com/2003/US/05/01/bush.transcript/index.html [accessed on 12 July 2007].

20. The question was asked by President Bush in his speech to Congress two weeks after the terror attacks and inspired numerous articles in almost all of the leading American newspapers. The book market has been flooded with similar questions on the prevalence of anti-Americanism, including Martin Oppenheimer's chapter "Why Do They Hate Us? Fighting Back" in his The Hate Handbook: Oppressors, Victims, and Fighters (Lanham: Lexington Books, 2005), Dick Martin's chapter "Why Do They Hate US?" in his book Rebuilding Brand America: What We Must Do to Restore Our Reputation and Safeguard the Future of American Business Abroad (New York: American Management Association, 2007) and chapters of the same title in Michael Prenti's Superpatriotism (San Francisco: City Lights Books, 2004), Melvin L. DeFleur's Learning to Hate Americans: How U.S. Media Shape Negative Attitudes Among Teenagers in Twelve Countries (Spokane: Marquette Books, 2003). Doris Chien-Yun Huang's has recently addressed this issue of hate in her thesis at Harvard University: Why Do They Hate Us? (And Do They?) Anti-Americanism in Mexico and Argentina, 1989-2006, Ph.D. thesis, 2006.

21. Alexis de Tocqueville, Democracy in America, translated and edited by Harvey C. Mansfield and Delba Winthrop (Chicago and London: University of Chicago Press, 2000), 227.

22. Although urban theorist Mike Davis acknowledges Los Angeles as the "First World capital of homelessness" with an estimated 100,000 homeless people, the city is notably absent in his comparative work Planet of Slums. Davis, Planet of Slums (London and New York: Verso, 2007), 36.

23. Wim Wenders "The American Dream" [1984] in On Film: Essays and Conversations, trans. by Sean Whiteside and Michael Hofmann (London: Faber and Faber, 2001) 126-127.

24. Huntington, American Politics, 68.

25. On the commentary track of the DVD Land of Plenty, Wenders expresses his anger with the way American patriotism has overlapped with religious trajectories. "That somebody like Paul, who has a slight tendency to become paranoid anyhow, fights against windmills which his President built up in front of him, need not surprise anyone. In any case, it seems as if the Americans were willing to accept anything during the first years after this tragic day in September of 2001. Their government unscrupulously exploited the reasonable fear and the fundamental shock in order to turn the country inside out according to its own agenda and to enforce conservative values thinly disguised with the cloak of Christianity."

26. Wenders, Land of Plenty, 2004, DVD.

27. Wenders, "The American Dream," 134.

28. Ibid.

29. Eric Rentschler, "How American Is It?: The U.S. as Image and Imaginary in German Film," The German Quarterly, 57: 4 (Autumn, 1984): 617.

30. In Germany, reviews were particularly harsh. Most critics considered Land of Plenty to be too moralistic and preachy. For a discussion of Wenders's religious undertones in Land of Plenty see Petra Grimm, "Utopie der Sanftmut. Land of Plenty als religöser Weltentwurf," in Volker Behrens, ed., Man of Plenty - Wim Wenders (Marburg: Schüren, 2005), 68-77. In the United States, Wenders had difficulties finding a distributor for Land of Plenty. It took about a year before the 
film could be shown in selected theatres. In an interview, Wenders explained that the liberal attitude towards Christianity exhibited by the main protagonist Lana in the film produced unforeseen difficulties in a country where Christianity is closely tied to issues of nationalism. "In the United States, Christianity is associated so much with right-wing conservatism and fundamentalism that distributors face a real problem. I did not expect this. There [in the United States], Christian ideas are so nationalistic that a liberal film can hardly be associated with a female protagonist, who lives her Christianity in a natural and naive way." Interview with Stefan Martini, "Los Angeles ist im Kino so oft zu sehen" (October 2004). See http://planet-interview.de/wimwenders-102004-05102004.html[accessed 28 June 2008].

31. O. A. Scott, "Land of Plenty: A Desire to Heal the Rifts in a Troubled Landscape," New York Times, 12 October 2005.

32. In a similar vein, film critic Stephen Holden emphasized that Wenders had produced a remarkably complex and insightful interpretation of fear and paranoia in The End of Violence. Ultimately, he remains the cultural outsider whose perspective is incompatible with the "reality" perceived by Americans: "His perspective on Hollywood and American mass culture has a wistfulness that feels quintessentially European. From a distance, Hollywood (and all the terrifying power exerted by its violent imagery over the global imagination) is finally just a world of dreams." Stephen Holden, "Is It Real, or Just a Bout of Paralyzing Paranoia?", New York Times, 12 September 1997. See http:// movies.nytimes.com/movie/review?

res=9E04EED71339F931A2575AC0A961958260 [accessed 15 March 2008].

33. Scott, "Land of Plenty."

34. During the aftermath of $9 / 11$, Wenders sensed a spirit of community among Americans and a deeper appreciation for the beauty of life which he hoped would lead to a "liberation of self-imposed narcissism." New encounters with American friends and American music helped him to feel at home again. "It has been almost two weeks,/ since I have returned to the United States./ Tonight, for the first time, I feel at home again." [Wenders: 2005, 229]. On that evening he listened to a newly released song by Leonard Cohen which would lead him to the spirit behind his first feature film after Million Dollar Hotel in the US. The sounds and lyrics of "Land of Plenty" suggest a truth which lies beneath the surface of American culture waiting to be revealed.

35. Quoted in Wenders, "Back in the US of A," 229.

36. Winfried Flück, "Heroic Loneliness: Hopper and the Imaginary Construction of an America We Love," unpublished manuscript, 2008.

37. Ibid.

38. In Wenders's The Million Dollar Hotel (2000), the peculiar atmosphere of Hopper's paintings is especially strong. 


\section{ABSTRACTS}

Independence Day and Land of Plenty are two tropes referring to the basis of American national identity: the Declaration of Independence with its guarantee of equal and inalienable rights and the promise of an inexhaustible abundance of resources. Independence Day and Land of Plenty are also two American feature films directed by German émigrés, the first being a science fiction blockbuster from 1996 by Roland Emmerich, the second an independent road movie from 2003 by Wim Wenders. Both films confront the issue of American patriotism albeit from different angles and at different times. Independence Day wholeheartedly embraces the American founding myths and translates them into a science fiction scenario. Wenders manoeuvres into an artistic space producing what I call patriotism of dissent. The films engage in a kind of dialectic dialogue on American patriotism. This article takes a close look at émigré perspectives on American patriotism before and after 9/11. By turning to the four patterns which political theorist Samuel P. Huntington identified as possible responses to the discrepancy between principles and practices of American democracy, I will analyse Independence Day as a filmic strategy to deny democratic gaps and Land of Plenty as a representative example of a moralistic reaction to democratic gaps. In the discourse of screening American patriotism from German émigré perspectives before and after 9/11, the work of Emmerich and Wenders exemplifies the spectrum of approaches to negotiate the fantasy of, desire for, and experience of American culture in the medium of film.

\section{INDEX}

Keywords: American dream, civic nationalism, cultural transfer, democratic gap, dissent, German-American cultural history, German-American directors, Marshall Plan, patriotism, science fictions films, transnationalism

\section{AUTHORS}

\section{FRANK MEHRING}

University of Berlin, Germany 